\title{
Text Editions of \\ (Abnormal) Hieratic, Demotic, \\ Greek, Latin and Coptic Papyri and Ostraca
}

Some people love their friends even when they are far away:

Festschrift in Honour of Francisca A.J. Hoogendijk

(P. L. Bat. 37)

Edited by

Joanne Vera Stolk

Guus A.J.C. van Loon

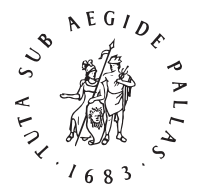

B R I L L

LEIDEN | BOSTON 


\section{Contents}

Table of Texts IX

Tabulagratulatoria XI

Preface XIII

Bibliography of Francisca A.J. Hoogendijk (up to 2019) XV

Abbreviated Literature XIX

Editorial Notation XXIV

\section{Text Editions}

1

'Afraid of What?' A Soothing Letter to Pharaoh's Workmen

(P. Turin Cat. 2022) 3

Ben J.J. Haring

2 Dead People Are Money! The Abnormal Hieratic Papyrus

Louvre N 2432 Revisited, and a Note on the Introduction of

Demotic in Sixth Century все Thebes 13

Koen Donker van Heel and Cary J. Martin

3 A Demotic Onomatological Fragment from North Saqqara 28 John Tait

4-14 Always Remember to Check the Back: A Closer Look at Some Published Ostraca in the British Museum and British Library 33 Adrienn Almásy-Martin and Cary J. Martin

15 'Paying Off the Lease': A New Demotic Document from the RMO 57

Steffie M.T. van Gompel

16 A Text Written with a Lack of Focus? Scribal Peculiarities in P. Leiden AMs 31a, a Copy of P. Brit. Mus. Iv 2166 Petra C. Hogenboom-Meijerink

17 A Report by Menches on Oil Smugglers Hiding Their Contraband in ... Dung 76

Nico Dogaer and Katelijn Vandorpe 
18 Aetolia Revisited: The Attribution of Pap.graec.mon. 34084 Annette Harder

19-21 Two Exercises in Writing Numbers and a Fragment of a Lease 91

Julia Lougovaya

22 Ein Formular für Eheurkunden 97

Joachim Friedrich Quack

23 Census Declaration 105

Roger S. Bagnall

24-25 Two Greek Texts from the Fayum 109

Mario Capasso

$26 \quad$ An Enslaved Woman Resold 114

Todd M. Hickey and James G. Keenan

$27 \quad$ A List of ousiai from Euhemeria 123

Yanne Broux and Willy Clarysse

28-29 Two Texts from Soknopaiou Nesos Concerned with

Water Supply 132

Sander de Weger

$30 \quad$ A Latin Letter from Carthage and the Whale-Bellied Jar 141

Rodney Ast

$31 \quad$ Alphabetical List of Villages $\quad 145$

Arthur Verhoogt

$32 \quad$ A Land Register 148

Gabriella Messeri

33 Letter or Petition with Complaint and Request about Garments for a Celebration 155

Eline Scheerlinck and Mattias Brand 
$34 \quad$ Lease Contract between Priests 159

Joanne Vera Stolk

$35 \quad$ Letter to a 'Father' $\quad 164$

Elena Chepel

$36 \quad$ An Official Deposition from the Early Fifth Century $\quad 167$

Amin Benaissa

37-38 Insiderhandel in Hermupolis? Ein neuer Blick auf

Stud.Pal. XX 143 und SB VI 9598171

Andrea Jördens

$39 \quad$ Fragment of a Loan Contract 184

Elsemieke S. Daalder and Quintijn H.C.L. Mauer

$40 \quad$ List of Tax Payments 189

Peter van Minnen

$41 \quad$ Lease Contract Subscribed by Elias Son of Paulos 196

Guus A.J.C. van Loon

42 A Protocol aperitionis testamenti from the Alexandrian

gesta municipalia 201

Constantinos Balamoshev

$43 \quad$ List of Payments 208

Csaba La'da

44-50 Seven Coptic Ostraca at the National Museum of

Antiquities in Leiden 212

Renate Dekker, assisted by Louis-Philippe Bazelier,

Dieneke Creemers, Omar Ghaly, Inge Schoonbrood,

Geertjan Versteegh and Chervan der Woude

$51 \quad$ List of Fugitives $\quad 225$

Nikolaos Gonis

$52 \quad$ Contract of Sale 228

Ruben de Graaf and Janneke de Jong 
$53 \quad$ List of Payments 232

Janneke de Jong

54-55 On Erring Monks, Literacy, and Materiality: A Re-edition of O. Crum ve $6 \quad 238$

Jennifer Cromwell

$56 \quad$ Account(s) of Deliveries of Wine 249

Alain Delattre

Index of Words in (Abnormal) Hieratic and Demotic

Scripts 253

Index of Words in Greek, Latin and Coptic $\quad 25^{8}$

Index of Sources $\quad 268$ 


\section{'Afraid of What?' A Soothing Letter to Pharaoh's Workmen (P. Turin Cat. 2022)}

\author{
Ben J.J. Haring
}

\author{
P. Turin Cat. 2022 \\ Deir el-Medina, ca. 1150-1100 BCE \\ TM 139481
}

The Museo Egizio in Turin is one of the richest repositories of pre-Hellenistic Egyptian papyri. Its collection includes papyrus documents from the Old Kingdom (Fourth Dynasty) through the Late Period, in addition to the Graeco-Roman and Coptic periods. A major part of the papyrus collection is from the Ramesside Period (ca. 1290-1070 BCE); virtually all of these papyri are from the Theban necropolis, and were acquired in 1823 from the French consul in Egypt, the Piemontese Bernardino Drovetti. They include literary and religious texts, but most are of a documentary nature, being the products of the administration of royal tomb construction during the Nineteenth and Twentieth Dynasties. The royal necropolis workmen were housed in a settlement near the Valley of the Kings and the Valley of the Queens, at a site presently known as Deir el-Medina. In recent years it has become ever more likely that the Drovetti papyrus lot is entirely from that site. ${ }^{1}$

Despite having been part of the Turin museum collection since 1823 , and in spite of their historical importance, many Turin papyri have never been properly published. Much of the material is even in a deplorable state, and consists of thousands of small fragments dispersed through hundreds of cardboard folders. A limited number of restored documents are in glass frames, but to date, only few of these have been published satisfactorily by modern scholarly standards. ${ }^{2}$ Fortunately, this state of

1 See B.J.J. Haring, 'Material Matters: Documentary Papyri and Ostraca in Late Ramesside Thebes', in: F.A.J. HoogendiJK S.M.T. van GoMpel (eds), The Materiality of Texts from Ancient Egypt. New Approaches to the Study of Textual Material from the Early Pharaonic to the Late Antique Period (P. L. Bat. 35, Leiden Boston, 2018), p. 44; R.J. Demarée - A. Dorn - S. Polis, 'Les listes de maisonnées de Deir el Médineh ("Stato civile"). Nouveaux fragments de l'IFAO et localization de l'archive d'une lignée de scribes', $B I F A O$, in press.

2 The only substantial documentary papyri published with photos, transcriptions and translations are several necropolis journals from the reigns of Ramesses IX and X: G. Вотti - T.E. PeEt, Il giornale affairs is to end very soon. Museum staff under the direction of Susanne Töpfer, and assisted by an international group of specialists, are currently restoring, scanning and studying the Turin Ramesside papyri. ${ }^{3}$ The aim of this project, the Turin Papyrus Online Platform, is to create a sophisticated online database with images and data, which will not only make all the material available for international scholarship, but also make it possible to work on it from a distance, for instance to reconstruct or partially reconstruct original documents from the mass of fragments. This enterprise was actually inspired by long-standing papyrological practice, online databases of Egyptian papyri of the Graeco-Roman period having been available for many years already.

Online databases, even with high-quality images and substantial metadata, are not the place for thorough discussions of ancient documents. For this, books and articles, online or printed, remain the preferred media. It is therefore with pleasure that I find myself in the position to offer an edition and discussion of a small but intriguing Turin papyrus text in this volume dedicated to my colleague and teacher Cisca. It was she who in the late 1980 os made me, a student of Egyptology, familiar with Greek papyri from Egypt, even before I began to concentrate on Egyptian ones. Since then I have frequently benefited from her expertise and continue to do so as a member of the Leiden 'Papyrology+' circle.

della necropoli di Tebe (Turin, 1928). Some smaller papyri have been fully published in articles. Many documents and fragments are available in the form of hieroglyphic transcriptions only.

3 See S. Töpfer, 'The Turin Papyrus Online Platform (TPOP): An Introduction', Rivista del Museo Egizio 2 (2018): https://rivista.museoegizio.it. The collaborating institutions include the universities of Basel, Copenhagen, Leiden, Leipzig, Liège, Munich and Uppsala. 


\section{Description}

H. $\times$ W. $=14 \times 16 \mathrm{~cm}$. Hieratic papyrus Turin Cat. 2022 (see photographs below) has so far remained unpublished. ${ }^{4}$ It has not yet been framed, but it is in a folder (numbered CPO8O/F334) in the museum's papyrus archive. It consists of several joined fragments of light and somewhat darker brown shades. It is incomplete, and additional fragments may very well be among the thousands of unpublished pieces in the museum's folders. ${ }^{5}$ Most of the text has been preserved, and if the ideas expressed below about the possible sender(s) and the epistolary formula are adequate, no line of the original text is missing entirely. No sheet join is visible, hence 'recto' here refers to the side on which the papyrus fibres run vertically, and which bears the first half of the text, consisting of six lines. The text on the verso side has seven lines, the top of the recto corresponding with the bottom of the verso. This means that the scribe turned the papyrus leaf vertically before continuing on the verso (as illustrated in Figure 1.1, on the left side).

The left edge of the papyrus is probably the original one, since no signs seem to be lost there, but the right part (approximately $4.5 \mathrm{~cm}$ of the original width) is missing. This can be inferred from the way the papyrus letter was folded in antiquity. Vertical cracks at approximately 4.5 and $10.5 \mathrm{~cm}$ from the left edge indicate that the letter was folded twice horizontally. Ancient Egyptian papyrus

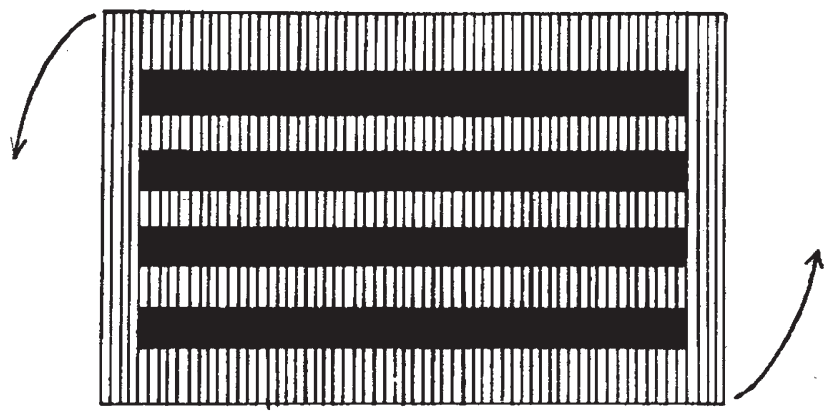

letters were usually rolled up vertically and then flattened, which resulted in multiple horizontal folds, and were then folded horizontally at least once (as shown in Figure 1.1, on the right side). ${ }^{6}$ Our letter was folded twice, as indicated by the cracks running from top to bottom, which represent the ancient folds - the present right edge of the papyrus was one of these. The original width of the papyrus must have been slightly more than $20 \mathrm{~cm}$. This reconstruction is supported by the width of most Ramesside papyrus letters, the sheets for which were cut from papyrus rolls in such a way that the width of the sheets were half the height of the rolls (which was $40-42 \mathrm{~cm}){ }^{7}$

The loss of the right part of the papyrus resulted in the loss of about a quarter of the text at the beginning of each line of the recto and the verso. In addition, recto line 2 lost its final one third, and only a few traces remain of recto line 1. This means that a strip of papyrus is lost at the top of the recto and the bottom of the verso. Further corresponding damage on the verso is the loss of the final one third of verso lines 5 and 6, while verso line 7 only left a small group of signs.

The horizontal cracks cannot all be identified with certainty; therefore, a reconstruction of the vertical folding will not be attempted here. After folding, the outside was inscribed with what is considered here the postscript (verso line 7); there are no traces of a sender or address that might have been written on the outside as well.

FIGURE 1.1 Writing and folding a papyrus letter (J. Černy, Late Ramesside Letters [BiAeg 9, Brussels, 1939], p. xix)

4 I wish to thank Susanne Töpfer of the Museo Egizio for permitting me to publish this papyrus, and for supplying me with the photos. I have benefited from preliminary transcriptions by Jaroslav Černý and Rob Demarée, which could be improved here marginally. I thank Rob Demarée and the Griffith Institute, Oxford, for making these transcriptions available to me. Jonny Russell kindly corrected my English. Hieroglyphic transcription was done with JSesh (available at: http://jseshdoc.qenherkhopeshef.org).

5 Searching all folders was not possible during the preparation of this article. A brief search of folders known to include fragments of letters did not yield any possible joins.

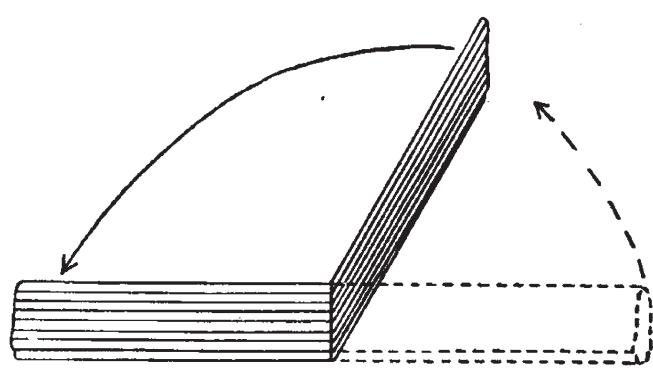

6 The procedure of writing and folding letters in Ramesside Egypt is best explained in ČERNÝ, Late Ramesside Letters, pp. xvii-Xx.

7 See ČERNÝ, op. cit., p. xviii; see also the material descriptions of papyrus letters in The Deir el-Medina Database (https://dmd.wep wawet.nl). 


\section{Introduction}

The addressees and the subject of the letter firmly connect it with the documentary texts left by the royal necropolis administration of the Ramesside Period, and therefore with the site of Deir el-Medina, where most of the Turin papyri from that period were probably found. The absence of personal names makes it difficult to establish a more precise date for the text, but it will be argued in the discussion below that its content ties in with historical developments known from the mid- to late Twentieth Dynasty. This, indeed, is the timeframe to which the majority of the Turin Ramesside papyri belong. ${ }^{8}$ The handwriting, which is characterized by an emphasis on tall verticals, cannot readily be connected with any other hieratic hand in the extant papyri from Deir el-Medina - which is no surprise since the sender was probably not a member of the community of the necropolis workmen. Therefore, it is of no help in dating the text more precisely. ${ }^{9}$

\section{Transliteration}

\begin{tabular}{|c|c|}
\hline \multicolumn{2}{|c|}{$\downarrow$ Recto } \\
\hline 1 & {$[------------] \ldots(?)[---]$} \\
\hline 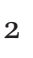 & {$[-----] n n з \operatorname{rmt} n$ p $3 \operatorname{Hr} \operatorname{s} p s[. y---]$} \\
\hline & {$[-----] s \underline{d} d m=i \operatorname{r} \underline{d} d$ twn snd $[\ldots] n$} \\
\hline & 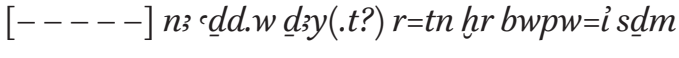 \\
\hline & {$[-----]$ snd n ih i.ir nim thetn } \\
\hline & 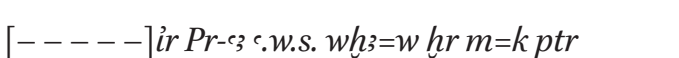 \\
\hline
\end{tabular}

$\leftarrow$ Verso

$1 \quad\left[---^{-}\right] . t w$ th=tn $m$ n; bik.w n Pr-c; c.w.s. $p 3 y=i$ $n b(?)$

$2 \quad[----t]$ wi i $m=f$ hr i. ir $=$ i $d w n r m h m t$ ts $y=f$

$3 \quad[-----]$ ih erer pзy sḥn $n$ Pr-ç c.w.s. $p 3 y=t n$

$4 \quad[n b \quad n f r \quad \ldots] \ldots(?) m t w=t n$ šsp p:y=tn ${ }^{\circ} q . w$ i.wn=w

$5 \quad[----\underline{h} r]$ h..tm dỉn $r$ rwd.w.w i.wn di.t $[---]$

$6 \quad[-----] \ldots(?) m t w=t n$ ir $=f m$ di $[---]$

Postscript in smaller characters:

$7 \quad[---------] s w 26 m \ldots(?)[---]$

\section{Translation}

\section{Recto}

1 ' $[-----------] \ldots(?)[---]$

$2 \quad[-----]$ to the men of the Noble Tomb $[---]$

3 [- - - - ] I heard: 'We are afraid!' ... (?)

$4\left[---^{-}\right]$the young men of evil (?) your mouth/ speech. But I have not heard

$5 \quad\left[---^{-}\right]$afraid of what? Who is going to attack you?

$6 \quad\left[---_{-}\right]$Pharaoh - life, prosperity, health searches for them. But look

Verso

$1 \quad[-----]$ one attacks you, the servants of Pharaoh life, prosperity, health - my Lord (?)

$2 \quad[-----]$ where I am. And I shall reach out and seize his

$3[-----]$ Do carry out this order of Pharaoh - life, prosperity, health - your

4 [Good Lord ...] ... (?) for you to receive your food rations which they used to

$5 \quad[-----]$ previously (?) from the agents who used to give $[---]$

$6 \quad[-----] \ldots$ (?) for you to do it. Do not (?)[-- ]'

7 ' $\left[------_{--}\right]$day 26 , having arrived/being done ... (?) $[---]$

in: R.J. Demarée - A. Egberts (eds), Deir el-Medina in the Third Millennium $A D$ (EgUit 14, Leiden, 200o), pp. 9-49; A. DorN S. Polis, 'Nouveaux textes littéraires du scribe Amennakhte (et autres ostraca relatifs au scribe de la tombe)',BIFAO 116(2016), pp.57-96; S.E. MCCLAIn, 'Authorship and attribution. Who wrote the twentieth dynasty journal of the necropolis?', in: A. Dorn - S. Polis (eds), Outside the Box. Selected papers from the conference "Deir el-Medina and the Theban Necropolis in Contact", Liège, 27-29 October 2014 (AegLeod 11, Liège, 2018), pp. 333-364. 


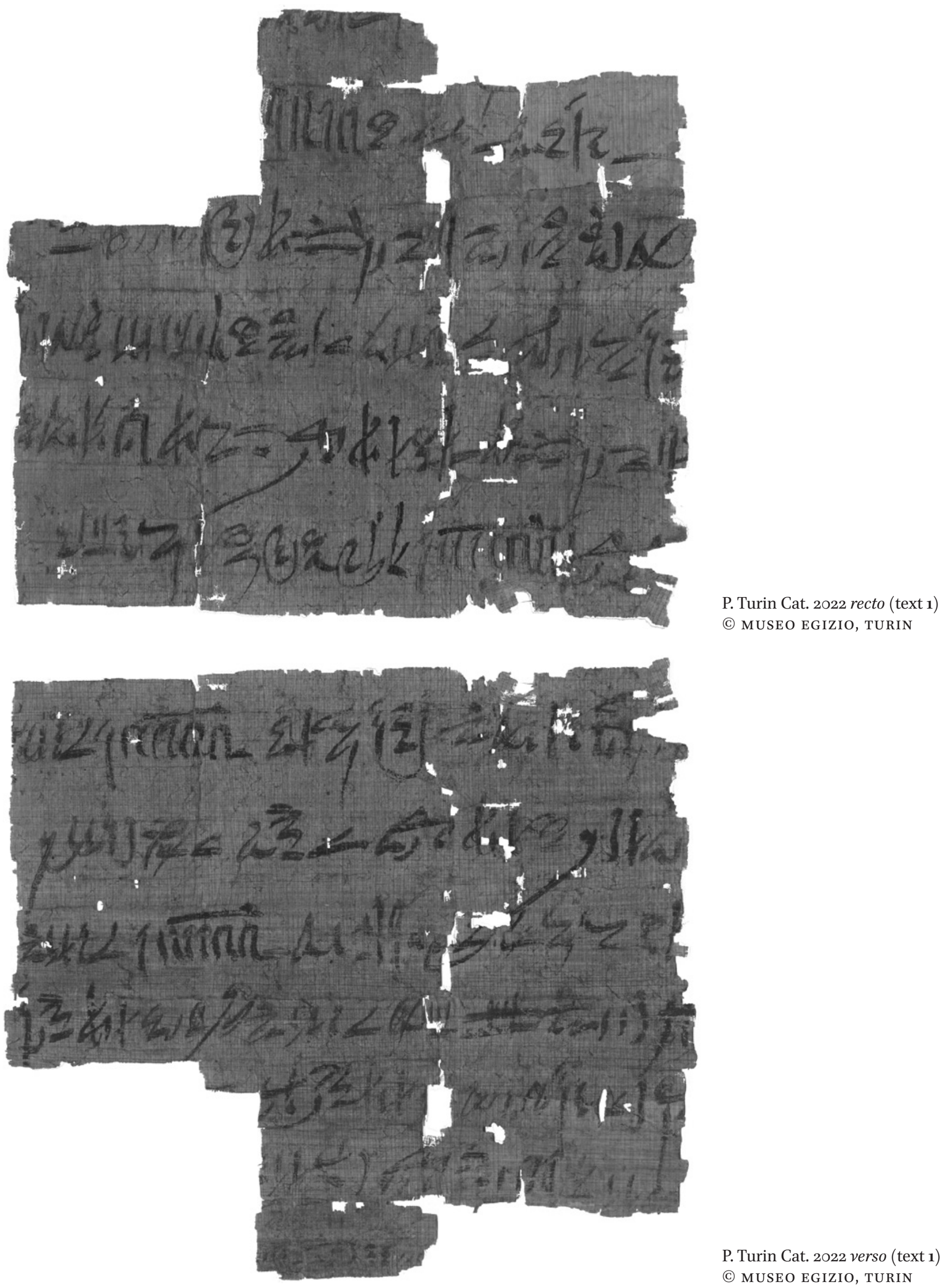

For use by the Author only | (C) 2021 Ben J.J. Haring 
Transcription

Recto

(traces only)

UIIIIII!

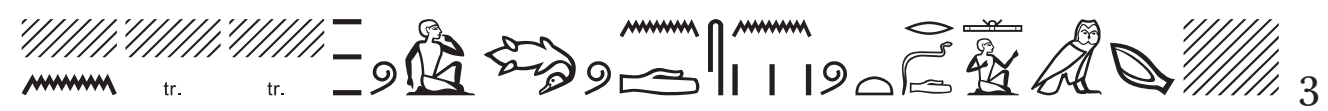

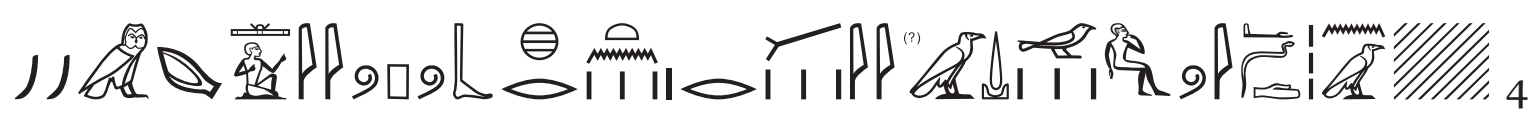

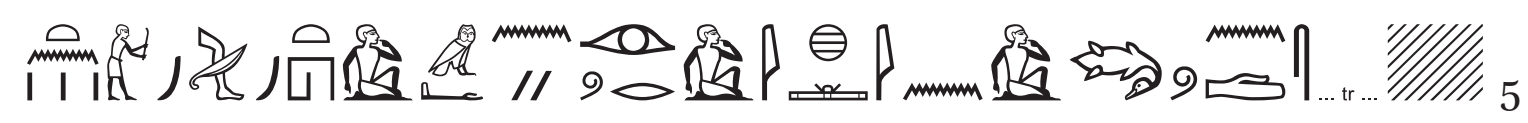

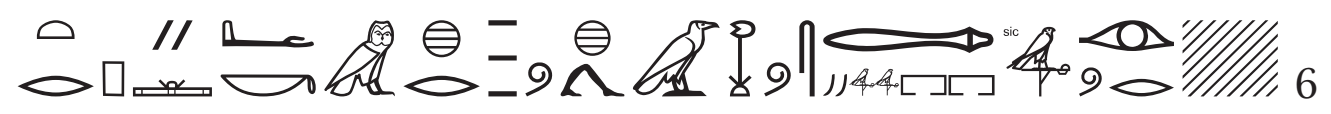

Verso

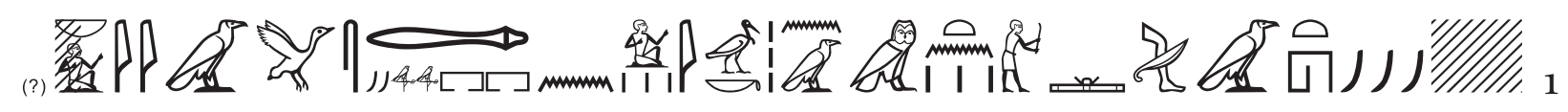

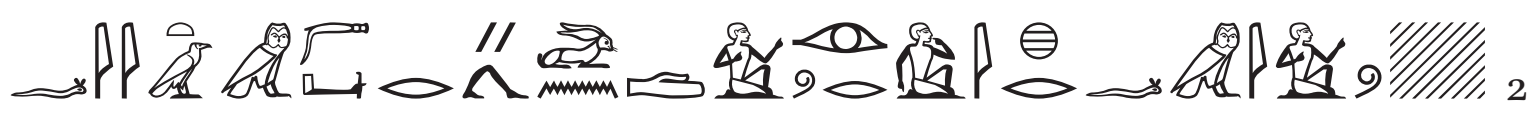

imilf

9.

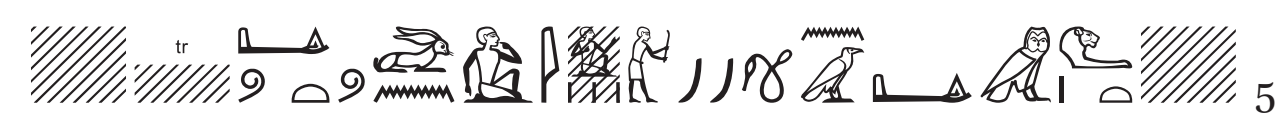

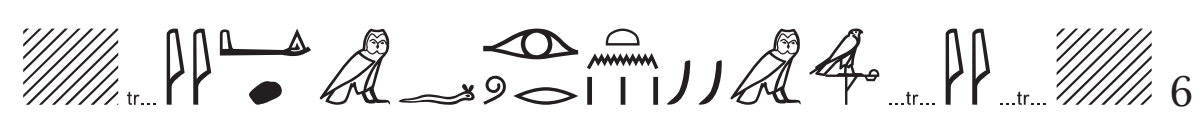

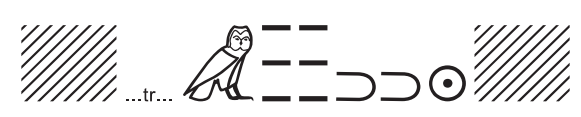




\section{Commentary}

Ro 1 One expects the sender to be mentioned here, before $n$ 'to' in recto 1.2 . The surviving traces may include those of $\_$(cf. di in verso ll. 5-6), 다 (cf. det. of erer in verso l. 3), or (cf. h3.t in verso l. 5). The latter sign is suggestive of the title '(military) leader' (h3.w.t.y). A less likely candidate is $\Omega_{-}$, as used for e.g. wnmy, in tzsy-hwy hr wnmy (n) nswt'fan-bearer at the right side of the King'. That title could be used by itself, but in Ramesside letters it was also held by the viceroy Panehsy and the military leader Paiankh and is attested most often for the vizier. Both suggested titles, however, are not supported by the traces surrounding the supposed or 2 .

rmt $n$ p ; $\mathrm{Hr}$ šps.y is known to me in this precise form only here; cf. rmt $n$ p s $\mathrm{Hr}$ c šps.y 'men of the Great and Noble Tomb' in Late Ramesside letters P. BM EA 10375 verso, 2; P. Turin CGT 54101 recto, 2-3. The full expression for the tomb of Pharaoh is $p$; Hr « šps.y $n$ hh.w $m$ rnp.w.t $n$ Pr-๕ cnh wd; snb 'the Great and Noble Tomb of Millions of Years of Pharaoh - life, prosperity, health'.

3 I take the group_-gafter snd 'to be afraid' to be purely graphic, and not a grammatical ending; snd, being intransitive, must be a stative here, and as such requires the ending .n, .wyn, or no ending at all. I can make nothing of the traces that follow.
The scribe lifted his brush before reaching the left edge of the papyrus, realising he would not be able to fit the entire word 1 spe left. The remaining signs are thus to be reconstructed at the beginning of verso 1.1 . The combination $m=k$ ptr is not uncommon; see e.g. P. Moscow 120 II 81-82: $m=k$ ptr ink iw.tw $w h$ s $=i \stackrel{s}{3}$ ch $h(r) w n b$ 'See: as for me, one will search for me until whatever day.' (A.H. GARDiner, Late Egyptian Stories [BiAeg 1, Brussels, 1932], 75). Preceded by hr: P. Chester Beatty I recto VII, 11-12: hr $m=k$ ptr ntk i.wp tw $\underline{d} s=k$ 'Now see: you are the one who judged himself!' (GARDINER, op. cit., 46).

Vo 1 The final signs of ptr (see note to recto l. 6) were followed by the start of a new sentence. The verb form could have been composed with twtw (introducing present tense), iw.tw (future) or i.ir.tw (emphatic), any one of which may have been preceded by the negation $b n$, or interrogative in. At the end possibly read $p ; y=i n b$, as transcribed by Černý (see n. 4) here and in verso 1.3 . The latter instance, however, looks different and should be read $p ; y=t n$. For the traces at the end of verso 1.1 as those of $p ; y=i n b$, cf. P. Bibliothèque Nationale 197, III recto 1. 4 and P. BM EA 75018 recto 1.3 .

2 Perhaps read $[n b$ nfr $m$; $n$ nty $t]$ wi im $=f$.

4 I have no explanation for the first group of signs preserved.

$5 \quad$ My hesitant 'previously (?)' assumes [ $\underline{h r}]$ ḥ.t. If correct, a verb with the meaning 'to give', 'to distribute' or one with a similar meaning must have preceded. 年 is suggestive of a divine or royal entity or name, but I am unable to say which.

$7 \quad$ sw 26 must have been preceded by month and season, and is followed by a faded group that similar postscripts elsewhere suggest might be $m$ ir.t, $m$ spr or $m \underline{d}$ r.t; cf. O. Berlin P 12367 (rnp.t-sp 5 IV šmw sw 16), O. Louvre E $11178 \mathrm{a}$ (II i h.t sw 6?), O. Strasb. H 174 (sw 9 m p ...?), P. BM EA 10419 (I h.t sw 9), P. DeM 28 ([...] sw $18 m$ ir.t šs $\underline{D} b n \underline{t} 3 t y)$, P. Turin Cat. 1971 (I šmw sw 20 spr $n$ Hr-n-'Imn-pne- $n=f)$, P. Egyptian Society of Papyrology, text B (iny.t $m$ rnp.t-sp 2 II šmw sw $13 m$ dr.t hr.y-hpt Hr), P. Turin Cat. 1896 (rnp.t-sp 6 IV ;h.t $s w 25)$. See note 12 for the latter two texts. 


\section{Discussion}

From the fact that the sender speaks in the first person singular, and the addressees are in the plural, we may infer that the latter are 'the men of the Tomb' in recto line 2, introduced by $n$ 'to'. The absence of a lengthy epistolary formula following the specification of the addressees - a very brief phrase such as 'in life, prosperity, health' might have been written at the end of recto line 2 and the beginning of recto line 3 - tells us that the sender's hierarchical position is far superior to that of the workmen. The words 'I heard' (recto l. 3) and 'I have not heard' (recto l. 4) further suggest that this person was not a member of the local community, but had to be informed over a distance, orally or in writing. The paternalistic tone of the letter indicates that the sender felt responsible for the men, while at the same time requiring them to continue the work despite distress. The first person that comes to the specialist's mind for this role is the vizier, who was the direct supervisor of royal tomb construction throughout the Ramesside Period, and as such in direct contact with local necropolis superiors. It is difficult to reconcile the few traces left of the first line on the recto as preserved with the vizier's titles (see note to recto l. 1), but the option should not be dismissed lightly: according to documentary texts connected with the royal necropolis workforce, the vizier was the high state official who was most often in contact with the workmen, usually by means of written correspondence (see below). Alternatively, one may think of other high functionaries who together with the vizier (or instead of him) supervised the necropolis workforce, especially from the middle of the Twentieth Dynasty onwards: the overseer of the royal treasury, royal butlers, the high priest of Amun, or the mayor of Thebes. ${ }^{10}$ None of these titles seem to be compatible with the traces in recto line 1 , either. Letters from viziers are rare among the extant papyri and ostraca. Letters demonstrably sent by a high priest, mayor, butler or treasury overseer are entirely absent; nor are these functionaries usually referred to as senders of letters in documentary necropolis records, as opposed to the vizier and the king." ${ }^{11}$ That the latter was the sender

10 See S. HÄggman, Directing Deir el-Medina. The External Administration of the Necropolis (USE 4, Uppsala, 2002), pp. $160-288$.

11 I do not know of any attestations of a mayor, butler or treasury overseer as sender. The high priest is mentioned once as the sender of a letter P. Turin Cat. $1898+$ recto II. The army general Payankh exceptionally mentions his title of high priest in Late Ramesside letter P. BM EA 10375. O. DeM $161+$ O. Strasb. H 82 mentions the high priest Ramessesnakht delivering a letter of P. Turin Cat. 2022 must be regarded as unlikely; surviving royal letters of the Ramesside Period (originals and models) are monumental both in size and appearance of document and script, and begin with extensive royal titularies, for which the present papyrus had no space. ${ }^{12}$ Also, the first person singular pronoun would have been written consistently as . No letters from the king to the workmen or their superiors appear to have survived, but they are referred to in documentary ostraca and papyri.13

If the vizier was in fact the sender, the first line of the recto as preserved (now represented by some traces only) could very well have been the first line of the letter in its original state. ${ }^{14}$ The rare letters from the vizier to the necropolis workforce that have survived start with his titles and name, which take hardly more than one line, and are followed by the classical formula $\underline{d} d n$ 'is the one who says to', without further epistolary phraseology. ${ }^{15}$ The addressees, introduced by a prominent stroke for $n$ 'to' (recto l. 2), are 'the men of the Noble Tomb'. To my knowledge, there are no other letters in which the workmen occur collectively and anonymously as addressees, without anyone in particular being specified. Letters by the vizier are usually addressed to the workmen's superiors. ${ }^{16}$

The absence of any personal name poses a major problem for the reconstruction of the historical background of the text and for establishing its date. The text makes

from, and taking letters to the king. The reader is referred to The Deir el-Medina Database (https://dmd.wepwawet.nl) for bibliographical and other data on the ostraca and papyri mentioned in this discussion.

12 See e.g. P. Turin Cat. 1896 (A. EL-M. BAKIR, Egyptian Epistolography from the Eighteenth to the Twenty-First Dynasty [BiÉtud 48, Cairo, 1970], pl. XXXI); P. Egyptian Society of Papyrology, text B (W. HeLCK, 'Eine Briefsammlung aus der Verwaltung des Amuntempels', JARCE 6 [1967], p. 147).

13 E.g. O. Cairo II 25504 rev. II 4, O. DeM $161+$ O. Strasb. H 82 obv. 4 (?), P. Turin Cat. 1879 verso E II 5 .

14 This assumption finds support in the postscript at the bottom of verso, which also indicates that nothing much is lost beneath.

15 The relevant letters include original letters as well as copies and writing exercises: O. DeM 114, P. BM EA 10731, P. DeM 28, P. Louvre $N 3169$ - it is not certain if the latter was addressed to the royal necropolis. Perhaps O. Michaelides 66 is to be included here as well, in view of its formula N.N. $d d n$ N.N. (for which see B.J.J. Haring, "In Life, Prosperity, Health!" Introductory Formulae in Letters from the Theban Necropolis', in: D. Kessler - R. SChUlZ - M. UllmanN - A. VerbovseK S. Wimme R (eds), Texte - Theben - Tonfragmente. Festschrift für Günter Burkard [ÄAT 76, Wiesbaden, 2009], pp. 187-188).

16 Extant letters (see the previous footnote): O. DeM 114 (to a chief workman), Р. BM EA 10731 (to the senior necropolis scribe), P. DeM 28 (to the two chief workmen). O. Ashmolean Museum 70 mentions a letter from the vizier to the 'captains' (hwt.y.w) of the Tomb, that is, to the chief workmen and the senior scribe. 
reference to very specific circumstances, but the words it uses pose more riddles to the modern reader than they give answers. Thus, we read about certain young men $\left({ }^{d} d d . w\right)$ who seem to represent malice or evil. Were they 'transgressors' (d di.w $^{2}$; see note to recto l. 4), or did they be-

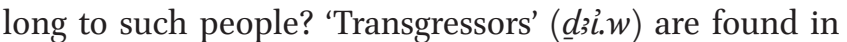
religious texts as entities to be repelled, together with th.w '(divine) attackers' and $m t . w$ ' (evil) dead' ${ }^{17}$ They could also be more earthly forces; thus the Egyptian soldier marching to Syria would face $\underline{d i} . w$ 'transgressors' hiding in shrubs, and hrw.y.w 'enemies' standing prepared for him..$^{18}$ The word ${ }^{2} z y . t$ can mean 'evil' in different ways, including unjust behaviour. The Decree of King Horemheb qualifies the unjust levying of dues from mayors as 'a case of transgression' (sp $n \underline{d} \underline{s} y . t) . .^{19}$ The author of P. Anastasi I had been given to understand: 'You are not a scribe at all! It (i.e. 'scribe') is an empty and meaningless name. You take up the (scribal) palette unjustly $(m \underline{d} ; y . t) .^{20}$

Even if the word $\underline{d} z y$ 'transgressor' or $\underline{d} 3 y . t$ 'transgression' is not to be read here, the determinative group i I I makes clear that the young men in question were up to no good or - alternatively - were victims of unjust behaviour. The plural $\stackrel{d}{d} d . w$ is found more often in Ramesside documentary texts from the Theban necropolis, as a reference to young workmen, perhaps apprentices (see note to recto 1. 4). The references include a couple of passages that might just theoretically be connected with our letter. Thus, P. Turin Cat. 1900 + verso I 13 relates how a necropolis guard reported to an official of Pharaoh about 'young men who were [...]'. The preceding lines tell us about work at the royal tomb, but they also cite a complaint made by the workmen, perhaps to the same official, that their food rations had been withheld from them. ${ }^{21}$ All this happened in regnal year 9 of Ramesses IX. Quite mysterious is the reference in P. Turin Cat. 1905 verso, 4 to young men, or one young man being 'attacked' or 'violated' (thi) in or about regnal year 12 of the same king. ${ }^{22}$ It is the combination of

17 So in P. Turin Cat. 1984 (text T.2 in I.E.S. EdwARDs, Oracular Amuletic Decrees of the Late New Kingdom [нрвм 4, London, 196o], p. 72, pl. XXVI).

18 P. Sallier I 7, 5 (A.H. GARdine R, Late-Egyptian Miscellanies [BiAeg 7, Brussels, 1937], p. 84; R. CAminos, Late-Egyptian Miscellanies [BEStud 1, London, 1954], pp. 318-319). Wb v, p. 517, no. 12 translates $\underline{d}_{3} i$. $w$ here as 'Strassenräuber'.

19 J.-M. Kruchten, Le Décret d'Horemheb. Traduction, commentaire épigraphique, philologique et institutionnel (Brussels, 1981), p. 98.

20 A.H. Gardiner, Egyptian Hieratic Texts Transcribed, Translated and Annotated I/1 (Leipzig, 1911), pp. $15^{*}$ and 22. KRI VI, 623; KRITA VI, 448-449.

22 KRI VI, 639; KRITA VI, 457. the words $e d d$ and thi that invites us to connect this particular piece of information with P. Turin Cat. 2022, but it is impossible to be certain if the connection is really there: the fragmentary text of Cat. 1905 verso, which otherwise only mentions work on textiles and possibly metal, is of little help.

To turn to another point raised in the letter, the one highlighted in the title of this contribution: what was it the workmen were afraid of (recto ll. 3, 5)? What problems are referred to here? One circumstance that is clear in Cat. 2022 is a problematic situation with respect to food supplies (verso ll. 4-5). This is, in fact, a well-known problem for the necropolis workforce during much of the Twentieth Dynasty. The workmen of the royal tomb did not earn a salary, but were given rations of food, clothing, and other things they required. The rations included a monthly quota of barley and emmer wheat, but from the end of the reign of Ramesses III onwards, these grain rations were often delayed. As a consequence, the workmen interrupted work at the royal tomb and sought the attention of the authorities, both their own (the vizier) and high local dignitaries, such as the mayor of Thebes, the high priest of the Karnak temple, and priests of the memorial temples at the edge of the Theban necropolis, close to their own settlement. These temples were often the destinations of protest marches and the locations of sit-ins, with which the authorities were none too pleased. In the famous Turin Strike Papyrus from regnal year 29 of Ramesses III, ${ }^{23}$ we read that the workmen 'passed the guard posts' (meaning: they were venturing outside their living and working area), and were marching to the nearby temples of Thutmose III, Ramesses II and Merenptah, demanding that the shortage of rations be reported to Pharaoh and the vizier. Their superiors (the senior necropolis scribe, the chief workmen and their deputies) urged the men several times to return to their own quarters, but a chief policeman of the necropolis advised them

P. Turin Cat. 1880: A.H. GARDInER, Ramesside Administrative Documents (Oxford, 1948), pp. 45-58; partial translation in W. Helck, Die datierten und datierbaren Ostraka, Papyri und Graffitivon Deir el-Medineh (Bearbeitet von A. Schlott) (ÄgAbh 63, Wiesbaden, 2002), pp. 304, 308-310, 313-315, 318; translation and discussion of recto: P.J. FrANDSEN, 'Editing Reality: The Turin Strike Papyrus', in: S. Israelit-Groll (ed.), Studies in Egyptology Presented to Miriam Lichtheim I (Jerusalem, 1990), pp. 166-199. Overview of the events, including other textual sources: J.J. JANSSEN, 'The Year of the Strikes', BSEG 16 (1992), pp. 41-49. 
otherwise, and told them to go to the temple of King Seti I together with their wives and children. In the course of the several months covered by the text, the workmen were given parts of their rations by the vizier and by the mayor of Thebes, and the vizier told them: 'It so happens that there is nothing even in the granaries; I shall give you what I have found!' (recto III, ll. 3-4).

These events took place in year 29 of Ramesses III, but the shortage of rations and the resulting actions of the workmen occurred again under later kings. In addition, another disturbing factor presented itself: the arrival of groups from the Libyan desert. Journals (day to day records) of the necropolis administration from the reigns of Ramesses IX and $x$ frequently mention the presence of these groups as a reason for interrupting work at the royal tomb: 'inactivity because of the foreigners/Rebu/ Meshwesh.' ${ }^{24}$ It remains uncertain in what capacity these groups appeared, for instance as marauding groups straight from the desert, or as Libyan units of the Egyptian army. We see them in the latter capacity in the Late Ramesside letters from the reign of Ramesses XI, as soldiers of the general Payankh who was fighting the king's former viceroy in Nubia, Panehsy. But it is the events in the necropolis journals from the reigns of Ramesses IX and $\mathrm{x}$ that constitute a more plausible historical background for the letter discussed in this contribution. The following events appear to be especially relevant.

Regnal year 8 of Ramesses IX, second month of Akhet, day 3. A letter was sent to the vizier and the 'scribe of the mat' (secretary of the Great Court of Thebes), asking for food rations and copper. By way of reply the workmen received a letter from the vizier and the scribe saying: 'The Meshwesh are coming to Thebes'. On day 14 of the same month, the workmen were inactive: 'It is said that the Meshwesh have come. ${ }^{25}$

Regnal year 9 of Ramesses IX, second month of Akhet, day [20?]. Men were being 'seized' $(m h)$ in the temple of

24 See B.J.J. HARInG, 'Libyans in the Late Twentieth Dynasty', in: R.J. Demarée - A. Egberts (eds), Village Voices. Proceedings of the symposium 'Texts from Deir el-Medina and their interpretation', Leiden, May 31-June 1, 1991 (CNws Publications 13; Leiden, 1992), pp. 71-80, and IDEM, 'Libyans in the Theban region, 2oth Dynasty', in: G.M. Zaccone - T.R. Di Netro (eds), Sesto Congresso Internazionale di Egittologia, Atti II (Turin, 1993), pp. 159-165, for outlines of these events.

25 P. Milan E $0.9 \cdot 40127$ + P. Turin Cat. 2074 recto II, ll. 7-9 and $\mathrm{X}+9$ : KRI VI, 6o9; KRITA VI, 442; R.J. Demarée, 'Ramesside Administrative Papyri in the Civiche Raccolte Archeologiche e Numismatiche di Milano', JEOL 42 (2010), pp. 69, 74-75.
Ramesses II (or, alternatively, men of that temple were 'seized'). On the previous days, the necropolis workforce had been working at the king's tomb, but there was also a search for grain rations. ${ }^{26}$

Regnal year 10 of Ramesses IX, fourth month of Peret and first month of Akhet. According to a necropolis journal, 'foreigners' were present, and work at the royal tomb was laid down for days. In addition, a workman called Pakharu was 'seized' together with other persons in, or belonging to, the temple of Seti I. ${ }^{27}$

Regnal year 13 of Ramesses IX, epagomenal days and first month of Akhet. No foreigners (or Rebu) were present, but no work was done, either. On day 2 of the first month of Akhet, an attendant of the vizier collected a letter for his superior from the supervisors of the necropolis workforce. ${ }^{28}$

Regnal year 14 of Ramesses IX, fourth month of Akhet. On day 27 , the workforce received a letter from the vizier, who had been informed by the necropolis physician Harsetiotef that the men were not going to work. A group of twenty men was mentioned in particular, and it was probably they who were 'seized at the entrance of the temple of Pharaoh - life, prosperity, health'.29

Regnal year 3 of Ramesses x, third and fourth month of Peret, and first month of Shemu. The gang of workmen was inactive for days because of the presence of 'foreigners', and they also suffered a lack of food rations. On day 1 or 2 of the first month of Shemu, the necropolis policeman Nesamun brought a letter from the high priest of Amun, who insisted that the men should go to work, but the same policeman told them not to. He was later called to account by the necropolis scribes 'concerning the matter of the letter of the [high] priest'. Later, on day 16 of the second month of Shemu, a letter from the vizier was delivered to the workforce by the mayor of Western Thebes;

26 P. Milan E 0.9.40126 + o.9.40128 verso III, l. $x+3$ : DEMARÉE, 'Ramesside Administrative Papyri', JEOL 42, pp. 64, 66, pl. II and IIa.

27 P. Turin Cat. 2071/14O: KRI VI, 637-638; KRITA VI, 456-457.

28 P. Turin Cat. $1999+2009$ verso I: Bотt - PeEt, Giornale, pl. 4-5; KRI VI, 563-564; KRITA VI, 418-419.

29 P. Turin Cat. 2071/139 recto II, ll. 9-15: S. Allam, Hieratische Ostraka und Papyri aus der Ramessidenzeit (URÄ̈ 1, Tübingen, 1973), pl. 122-124; KRI VI, 641-642; KRITA VI, 459. See HELCK, Die datierten und datierbaren Ostraka, p. 508, and K. GABLER, Who's who around Deir el-Medina. Untersuchungen zur Organisation, Prosopographie und Entwicklung des Versorgungspersonals für die Arbeitersiedlung und das Tal der Könige (EgUit 31, Leiden Leuven, 2018), p. 713, for Harsetiotef as the name of the physician in recto II, l. 10. The alternative translation 'The doctor Hori (is now) 〈in〉 the place of his father' (KRITA VI, 459) is less plausible. 
very possibly, this letter also urged the men to resume their work. ${ }^{30}$

We cannot be certain if any of the events mentioned in the previous paragraphs are actually referred to in P. Turin Cat. 2022. Yet the lack of food rations, and the men's refusal to go to work in connection with the presence of foreign groups, may well be what our letter is hinting at. And our mischievous young men (recto l. 4) were perhaps among the men 'seized' in years 9,10 or 14 of Ramesses Ix. We may even be tempted to assume that

30 P. Turin Cat. $1898+1937+2094 / 244$ recto I-III: BotTI - PeEt, Giornale, pl. 50-54; KRI VI, 687-693; KRITA VI, 486-489. one of the letters mentioned in year 14 of Ramesses IX and year 3 of Ramesses $x$ is, in fact, our letter. If it is not, ${ }^{31}$ it is still likely that the letter was sent to the necropolis workmen in very similar circumstances.

Whatever its precise date and background may be, the letter P. Turin Cat. 2022 shows us that even in the face of danger and food shortage, 'Keep calm and carry on' remained the creed of the Ramesside necropolis workmen's superiors.

31 'Day 26' in verso l. 7, if read correctly, does not correspond with any of the dates on which a letter arrived according to the journal entries discussed. 